Prepared in cooperation with Public Utility District Number 1 of Lewis County, Washington Distribution of Adult Chinook Salmon (Oncorhynchus tshawytscha) in Relation to Water Temperatures, Lake Scanewa, Cowlitz River, Washington, 2012

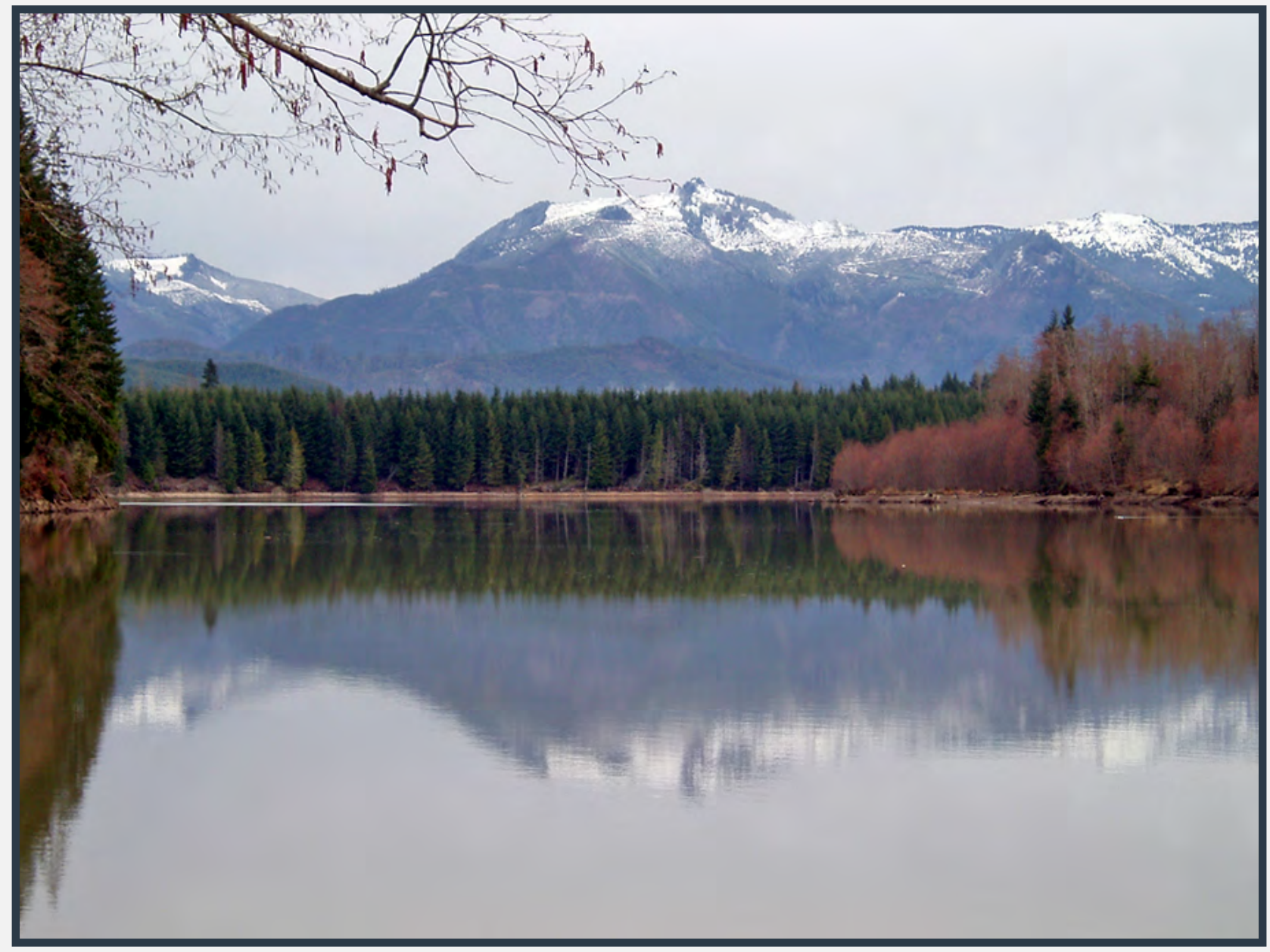

Open-File Report 2019-1055 
Cover: Lake Scanewa as seen looking upstream from Cowlitz Falls Dam, Washington. Photograph by Brian K. Ekstrom, U.S. Geological Survey, 2007. 


\section{Distribution of Adult Chinook Salmon (Oncorhynchus tshawytscha) in Relation to Water Temperatures, Lake Scanewa, Cowlitz River, Washington, 2012}

By Tobias J. Kock, Brian K. Ekstrom, and Theresa L. Liedtke

Prepared in cooperation with Public Utility District Number 1 of Lewis County, Washington

Open-File Report 2019-1055

U.S. Department of the Interior

U.S. Geological Survey 


\section{U.S. Department of the Interior \\ DAVID BERNHARDT, Secretary}

\section{U.S. Geological Survey James F. Reilly II, Director}

U.S. Geological Survey, Reston, Virginia: 2019

For more information on the USGS-the Federal source for science about the Earth, its natural and living resources, natural hazards, and the environment-visit https://www.usgs.gov/ or call 1-888-ASK-USGS (1-888-275-8747).

For an overview of USGS information products, including maps, imagery, and publications, visit https://store.usgs.gov/.

Any use of trade, firm, or product names is for descriptive purposes only and does not imply endorsement by the U.S. Government.

Although this information product, for the most part, is in the public domain, it also may contain copyrighted materials as noted in the text. Permission to reproduce copyrighted items must be secured from the copyright owner.

Suggested citation:

Kock, T.J., Ekstrom, B.K., and Liedtke, T.L., 2018, Distribution of adult Chinook salmon (Oncorhynchus tshawytscha) in relation to water temperatures, Lake Scanewa, Cowlitz River, Washington, 2012: U.S. Geological Survey Open-File Report 2019-1055, 14 p., https://doi.org/10.3133/ofr20191055.

ISSN 2331-1258 (online) 


\section{Contents}

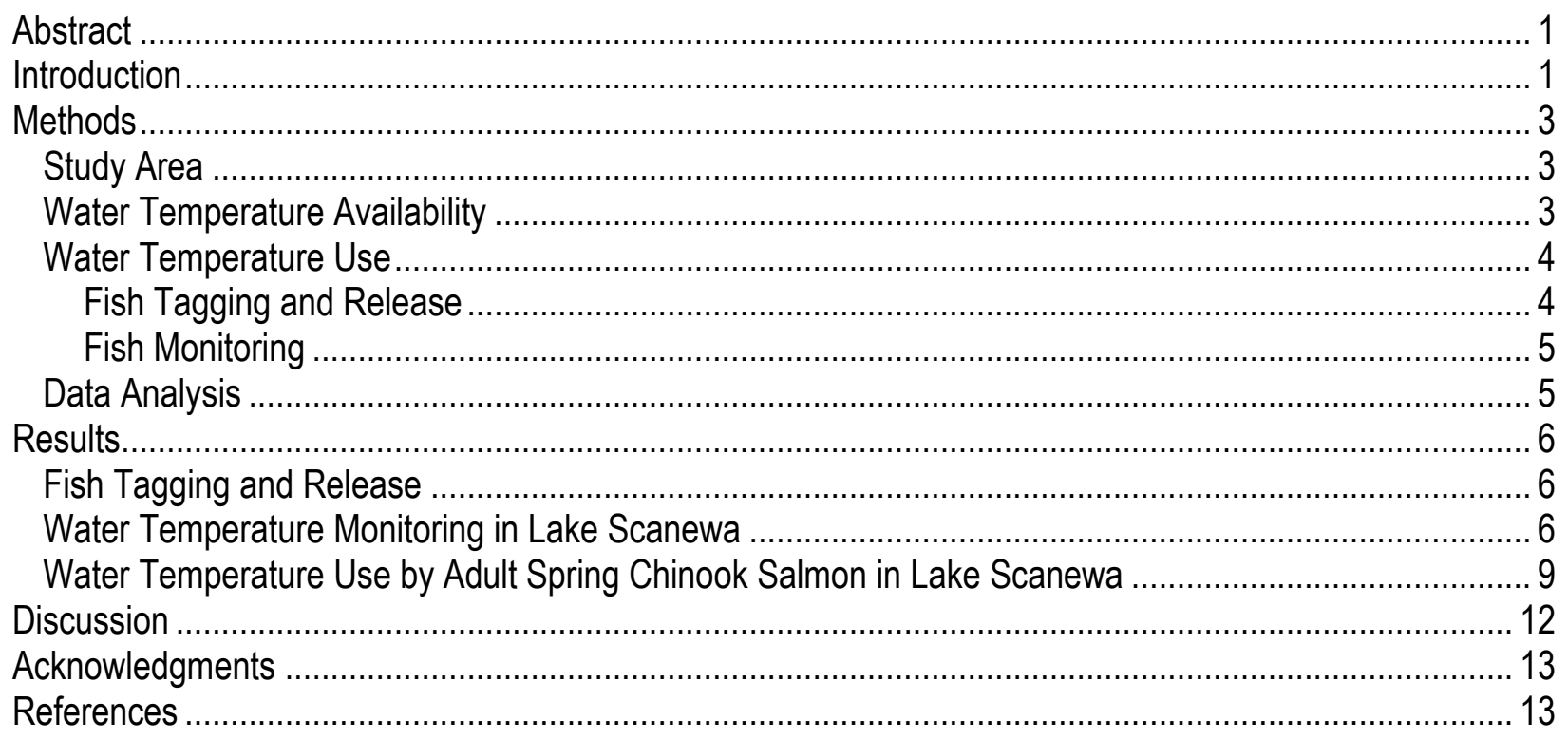

\section{Figures}

Figure 1. Map showing locations of telemetry monitoring sites (open circles), water temperature loggers (filled circles), and the release site (filled square) where spring Chinook salmon (Oncorhynchus tshawytscha) entered Lake Scanewa, Cowlitz River, Washington.

Figure 2. Graph showing daily water temperature at the Cowlitz Falls Fish Facility, Cowlitz Falls Dam, Washington, from April 16 to August 31, 2008-16.................................................................... 7 Figure 3. Graph showing depth-specific mean daily water temperatures at three sites in Lake Scanewa, Cowlitz River, Washington, July-September 2012.

Figure 4. Graph showing mean daily water temperature use by three individual adult Chinook salmon (Oncorhynchus tshawytscha) in Lake Scanewa, Cowlitz River, Washington, 2012. 10

Figure 5. Graphing showing mean daily water temperature use by tagged adult Chinook salmon in Lake Scanewa, Washington, 2012.

Figure 6. Graph showing mean daily water temperature use by adult Chinook salmon in three regions (Cispus arm, Cowlitz arm, and Downstream arm) of Lake Scanewa, Washington, 2012

\section{Tables}

Table 1. Summary of water depths where water temperature loggers were deployed, Lake Scanewa, Cowlitz River, June-October 2012

Table 2. Number of male and female hatchery origin Chinook salmon (Oncorhynchus tshawytscha) tagged and released to evaluate water temperature use patterns in Lake Scanewa, Cowlitz River, Washington, 2012

Table 3. Number of radio-tagged Chinook salmon (Oncorhynchus tshawytscha) detected monthly from June to October 2012, Lake Scanewa, Cowlitz River, Washington ..

Table 4. Number of temperature records collected by 1 degree Celsius intervals from radio transmitter detections in Lake Scanewa, Cowlitz River, Washington, during June-October 2012 


\section{Conversion Factors}

U.S. customary units to International System of Units

\begin{tabular}{|c|c|c|}
\hline Multiply & By & To obtain \\
\hline \multicolumn{3}{|c|}{ Flow rate } \\
\hline cubic foot per second $\left(\mathrm{ft}^{3} / \mathrm{s}\right)$ & 0.02832 & cubic meter per second $\left(\mathrm{m}^{3} / \mathrm{s}\right)$ \\
\hline \multicolumn{3}{|c|}{ International System of Units to U.S. customary units } \\
\hline Multiply & By & To obtain \\
\hline \multicolumn{3}{|c|}{ Length } \\
\hline centimeter $(\mathrm{cm})$ & 0.3937 & inch (in.) \\
\hline millimeter (mm) & 0.03937 & inch (in.) \\
\hline meter (m) & 3.281 & foot $(\mathrm{ft})$ \\
\hline kilometer $(\mathrm{km})$ & 0.6214 & mile (mi) \\
\hline \multicolumn{3}{|c|}{ Area } \\
\hline square kilometer $\left(\mathrm{ft}^{2}\right)$ & 247.1 & acre \\
\hline
\end{tabular}

Temperature in degrees Celsius $\left({ }^{\circ} \mathrm{C}\right)$ may be converted to degrees Fahrenheit $\left({ }^{\circ} \mathrm{F}\right)$ as:

${ }^{\circ} \mathrm{F}=\left(1.8 \times{ }^{\circ} \mathrm{C}\right)+32$.

\section{Abbreviations}

DOD U.S. Department of Defense

EPA U.S. Environmental Protection Agency

ppm part per million

USGS U.S. Geological Survey 


\title{
Distribution of Adult Chinook Salmon (Oncorhynchus tshawytscha) in Relation to Water Temperatures, Lake Scanewa, Cowlitz River, Washington, 2012
}

\author{
By Tobias J. Kock, Brian K. Ekstrom, and Theresa L. Liedtke
}

\begin{abstract}
A trap-and-haul program is operated to move anadromous Pacific salmon (Oncorhynchus spp.) around dams and reservoirs in the Cowlitz River basin, Washington. The primary release site for adult fish is in Lake Scanewa, a small reservoir created by Cowlitz Falls Dam, the uppermost dam in the basin. Releases in the reservoir are terminated when reservoir water temperature is 16 degrees Celsius $\left({ }^{\circ} \mathrm{C}\right)$ or greater to reduce the risk of exposing adult salmon and steelhead (O. mykiss) to thermal conditions known to be stressful for these species. When the water temperature limit is reached, fish are released into the Cowlitz and Cispus Rivers upstream of the reservoir. Concerns have been raised about fish presence in the reservoir during warm conditions, so an empirical evaluation of water temperatures selected by spring Chinook salmon (O. tshawytscha) in Lake Scanewa was requested by resource managers. We conducted the evaluation during June-October 2012. Water temperature in the reservoir was measured using a series of thermographs combined with daily measurements at the Cowlitz Falls Fish Facility. Temperature-use data were collected from 50 adult hatchery-origin spring Chinook salmon tagged with temperature-sensing radio transmitters and released into the reservoir. This approach yielded a total of 930,056 individual temperature-use records in the reservoir during the study. Tagged fish occupied water temperatures less than $16^{\circ} \mathrm{C}$ during most of the study period. Water temperatures ranged from 5 to $18.5^{\circ} \mathrm{C}$ during the study, peaking in mid-August. Overall, about 25 percent of the detections of tagged fish were in water temperatures in the $16-20{ }^{\circ} \mathrm{C}$ range. In August, tagged fish detections in the $18-20^{\circ} \mathrm{C}$ range comprised 13 percent of the total detections, and the remainder of the detections were in water less than or equal to $17^{\circ} \mathrm{C}$. Results from the study indicate that adult hatchery-origin spring Chinook salmon were able to locate and use water temperatures in the reservoir less than levels associated with stress. However, we also observed that thermal conditions in the reservoir were cool relative to most other years during 2008-16. Additional research may be warranted to better understand thermal exposure of adult spring Chinook salmon during warmer years.
\end{abstract}

\section{Introduction}

Pacific salmon (Oncorhynchus spp.) were excluded from the upper Cowlitz River basin in the 1960s when Mayfield and Mossyrock dams were constructed at river kilometer (rkm) 84 and 105. However, the mid-1990s construction of Cowlitz Falls Dam (rkm 142), which included a surface collection system to capture downstream migrants, provided an opportunity to reintroduce anadromous fish species to the upper Cowlitz River basin (Serl and Morrill, 2011). The reintroduction effort included the development of a trap and haul program that moves 
juvenile and adult fish around Cowlitz River dams. Adult salmon and steelhead (O. mykiss) that return to spawn in the Cowlitz River are collected downstream of Mayfield Dam. These fish are sorted at the collection facility, and adult fish destined for the upper Cowlitz River basin are transported and released upstream of Cowlitz Falls Dam to spawn naturally. Juvenile salmon and steelhead that are progeny of transported adults eventually move downstream toward the ocean and encounter Cowlitz Falls Dam where they can be collected and transported downstream of Mayfield Dam. The reintroduction has successfully established populations of steelhead, Chinook salmon (O. tshawytscha), and coho salmon (O. kisutch) to areas upstream of Cowlitz Falls Dam (Serl and Morrill, 2011). These efforts are continuing, with the goal of eventually establishing self-sustaining populations in the basin.

Three release sites were developed upstream of Cowlitz Falls Dam to facilitate fishhauling trucks releasing adult salmon and steelhead. The primary release site is in Lake Scanewa (fig. 1), the reservoir created by Cowlitz Falls Dam. At this site, fish enter the reservoir near the confluence of the Cowlitz and Cispus Rivers. Spawning habitat is nearly absent in Lake Scanewa, but released fish can choose to enter either the Cowlitz or Cispus Rivers, which each contain abundant spawning areas. Secondary release sites were established in the Cowlitz and Cispus Rivers. The Cowlitz River release site is located near Packwood, Washington, about 58 rkm upstream of the Lake Scanewa release site. The Cispus River release site is located about 32 rkm upstream of the Lake Scanewa release site (fig. 1). The primary release site in the reservoir has advantages: it has the shortest transport time (from the adult collection facility downstream of Mayfield Dam to the release site) of all three release sites, and fish can select to enter either the Cowlitz River or Cispus River for spawning. However, there are also concerns associated with releasing fish in the reservoir: the release site is located a short distance upstream (1.6 rkm) of Cowlitz Falls Dam, so fish may be susceptible to falling back downstream of the dam, and reservoir water temperatures can exceed 20 degrees Celsius $\left({ }^{\circ} \mathrm{C}\right)$ during summer months. The potential for warm reservoir water temperatures to negatively affect transported fish is of concern for Chinook salmon. Most Chinook salmon are transported upstream and released during April-June, but some fish are also released during July and August. To minimize potential negative effects of increased water temperature, resource managers typically choose to use the Cowlitz and Cispus River release sites when water temperature exceeds $16{ }^{\circ} \mathrm{C}$ in Lake Scanewa. This trigger has recently been modified to begin using the river release sites on June 16 , which is generally when reservoir conditions reach $16^{\circ} \mathrm{C}$ each year. Many Chinook salmon adults remain in Lake Scanewa for weeks after release, particularly those of hatchery origin (Kock and others, 2016; Kock and others, 2018). Thus, many of the spring Chinook salmon released into the reservoir each year may be exposed to water temperatures greater than $16{ }^{\circ} \mathrm{C}$ if they remain in the reservoir for an extended period. Previous research has shown that thermal conditions greater than $18{ }^{\circ} \mathrm{C}$ are stressful for spring Chinook salmon (Berman, 1990; McCullough and others, 2001), and exposure to temperature conditions in this range can negatively affect fish health, survival, and fitness (Keefer and others, 2015).

We initiated this study to evaluate water temperature availability and water-temperature use by adult spring Chinook salmon in Lake Scanewa during 2012. Water temperature availability data were collected using thermographs deployed throughout the study area. Watertemperature-use data were collected by tagging adult spring Chinook salmon with temperaturesensing radio transmitters. The objectives of the study were to: (1) describe water temperature patterns in Lake Scanewa during June-September 2012, and (2) describe water, temperature use 
by adult spring Chinook salmon during June-September 2012. This report summarizes the study done to address these objectives.

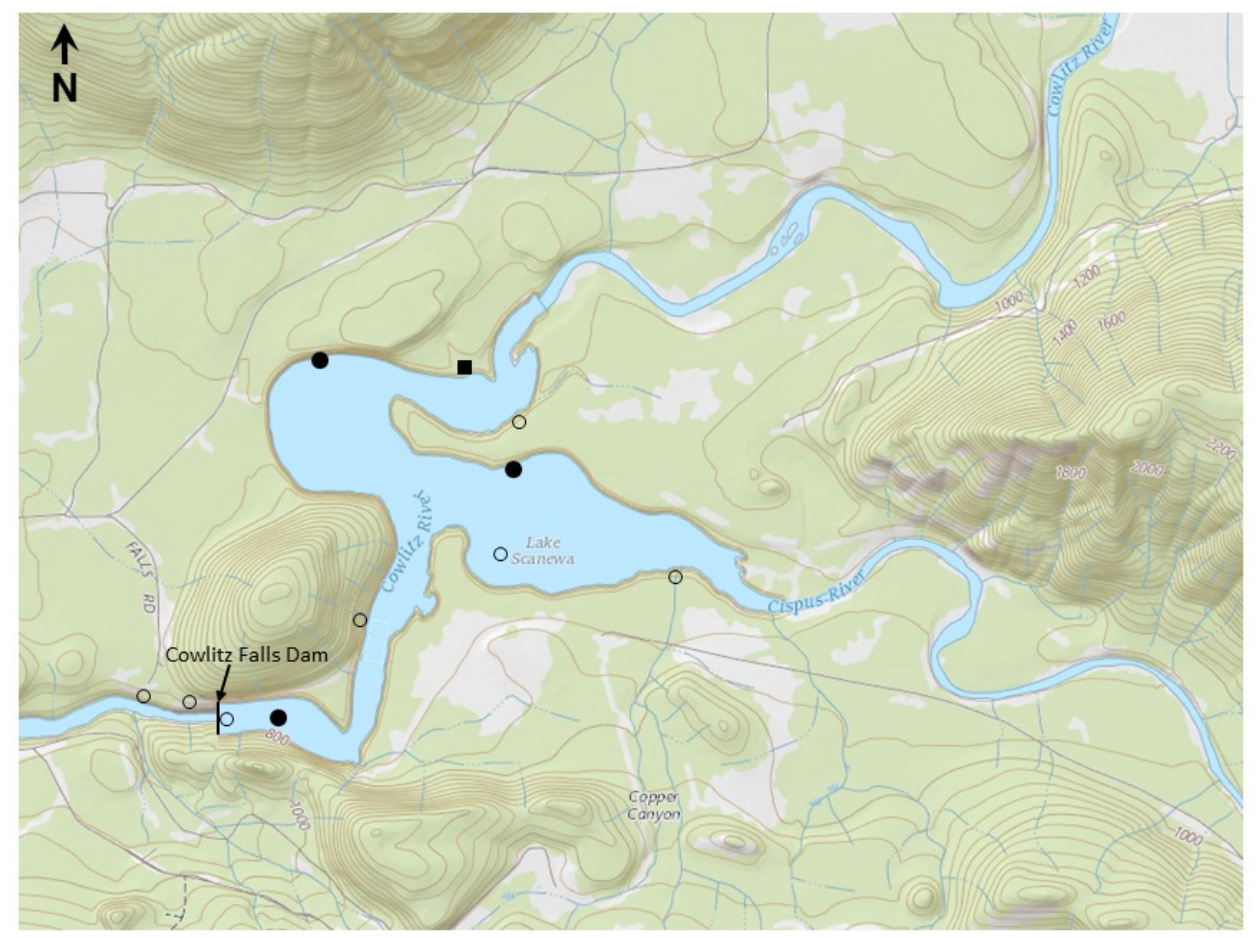

Figure 1. Map showing locations of telemetry monitoring sites (open circles), water temperature loggers (filled circles), and the release site (filled square) where spring Chinook salmon (Oncorhynchus tshawytscha) entered Lake Scanewa, Cowlitz River, Washington.

\section{Methods}

\section{Study Area}

The Cowlitz River in southwestern Washington state is a primary tributary to the lower Columbia River. The river drains 6,698 square kilometers $\left(\mathrm{km}^{2}\right)$ on the western slopes of the Cascade Mountain range. The three dams operating on the river are the Mayfield, Mossyrock, and Cowlitz Falls Dams. The upper Cowlitz River basin is comprised of two main rivers, the Cowlitz River and the Cispus River. They share a confluence at rkm 144, near the center of Lake Scanewa, a small reservoir with a surface area of 264 hectares. The Cowlitz River upstream of Cowlitz Falls Dam drains $1,577 \mathrm{~km}^{2}$, and the Cispus River drains $1,121 \mathrm{~km}^{2}$. This study was done within the boundaries of Lake Scanewa (see section, "Fish Monitoring") to describe watertemperature use by adult spring Chinook salmon in the reservoir.

\section{Water Temperature Availability}

Water temperature was monitored in Lake Scanewa at three locations: the Cowlitz arm, the Cispus arm, and the downstream arm of the reservoir (fig. 1). Multiple temperature loggers (Model HOBO Pro v2, Onset Computer Corporation, Bourne, Massachusetts) were vertically 
separated at each site to collect water temperature data at specific depths in the water column (table 1). Water temperature loggers were attached to a 0.6 centimeter-diameter steel cable anchored to the reservoir floor with a $13.6 \mathrm{~kg}$ lead weight. The steel cable was attached at the surface to a large tree root or stump, which allowed it to suspend vertically in the water column. Deployment depths of water temperature loggers at each location are shown in table 1.

Temperature loggers were programmed to record a temperature reading every 2 hours $(\mathrm{h})$. These records were averaged for each calendar day to summarize daily-averaged water temperature at each depth for all locations. Additionally, daily water temperature records were obtained from the Cowlitz Falls Fish Facility, which is operated from mid-April to late-August each year.

Table 1. Summary of water depths where water temperature loggers were deployed, Lake Scanewa, Cowlitz River, June-October 2012.

\begin{tabular}{ll}
\hline \multicolumn{1}{c}{ Location } & Depths (meter) \\
\hline Cispus arm & $0,1,3$ \\
Cowlitz arm & $0,1,3,5$ \\
Downstream arm & $0,1,3,5,7,9$ \\
\hline
\end{tabular}

\section{Water-Temperature Use}

\section{Fish Tagging and Release}

Adult spring Chinook salmon were collected for tagging at the Cowlitz Salmon Hatchery (rkm 113.7) downstream of Mayfield Dam. The fish trap at the hatchery operates continuously during periods when adult salmon and steelhead are migrating. Fish are handled and sorted weekdays by Tacoma Power staff. An automatic crowder was inside the fish trap, and an exit chute was near the top of the trap that led to the area where anesthesia was administered. The crowder was used to force groups of fish (20-50 fish/group) into the exit chute for batch application of anesthesia. Fish were anesthetized using electrosedation (Model EA-1000B, Smith-Root, Inc., Vancouver, Washington) to facilitate the sorting process. Groups of fish were crowded into a large holding basket, and electrosedation was applied for approximately 30 seconds, after which fish were immobilized and ready for sorting. Fish were sorted by species and origin and moved into one of eight concrete holding tanks, where they could be transferred to the hatchery for spawning or loaded onto fish hauling trucks and transported to upstream release sites. Tagging occurred after fish were sorted and before fish were transferred to the holding tanks.

For this study, tagging was restricted to hatchery-origin fish that had been shown to spend more time in the reservoir than their natural-origin counterparts (Kock and others, 2018). We collected the following data for each tagged fish: species, sex (visually assessed), and fork length (centimeter). Once these data were collected, a radio transmitter was gastrically implanted using methods described by Keefer and others (2004). We used MCFT-3EM transmitters (Lotek Wireless, Inc.; Newmarket, Ontario, Canada) that were 53-millimeter-long and 12-millimeterwide and weighed 4.3 grams in water. A single band of silicon tubing (approximately 1centimeter long) was placed around the lower part of each transmitter to decrease the likelihood that transmitters were regurgitated (Keefer and others, 2004). Following tagging, fish were transferred to a concrete holding tank where they were held overnight (along with untagged fish) to recover from the trapping, sorting, and tagging process. 
On each release day, groups of fish were loaded onto fish-hauling trucks for transport to the upper Cowlitz River basin. All loading and transport processes were done by Tacoma Power personnel, following the procedures used for the trap-and-haul program. The radio-tagged fish were loaded and transported under the same conditions as untagged fish. The loading process consisted of a water-to-water transfer from the holding tank to the fish-hauling truck. Transport trucks hauled approximately 130 Chinook salmon in each load, and tagged fish were transported with untagged fish. Transport time from the Cowlitz Salmon Hatchery to the Lake Scanewa release site was approximately 45 minutes. Releases normally occurred between 09:00 and 11:00 a.m. Fish were released directly from the transport truck into the river at the release site using a 1-meter-long flume that minimized the vertical drop from the truck to the river.

Fish Monitoring

A series of fixed-location monitoring sites (hereinafter called "fixed sites") were deployed to detect tagged fish as they moved within the study area. Six fixed sites monitored fish and temperature use in Lake Scanewa. These sites were in the reservoir in the Cowlitz Arm (rkm 162), near the Day Use Park (rkm 146), in the Cispus Arm ( $\mathrm{rkm} 2)$, near the confluence of the Cowlitz and Cispus rivers (rkm 0.5), downstream of the confluence (rkm 143), and in the forebay of Cowlitz Falls Dam (rkm 142; fig. 1). Several other fixed sites were deployed outside of the reservoir to determine when tagged fish left Lake Scanewa. These sites were located inside the Cowlitz Falls Fish Facility (rkm 141), in the tailrace of Cowlitz Falls Dam (rkm 141), downstream of Cowlitz Falls Dam near the head of Riffe Lake (rkm 137), in the forebay of Mossyrock Dam (rkm 105), near Yellowjacket Creek on the Cispus River (rkm 27), on the Cispus River (rkm 11), near Packwood, Washington on the Cowlitz River (rkm 201), and on the Cowlitz River (rkm 181). Each fixed site contained a telemetry receiver (Model SRX-600; Lotek Wireless, Inc., Newmarket, Ontario, Canada) connected to one or two Yagi antennas. Power was provided by a 12-volt battery recharged by a solar panel.

Fixed-site detection data were supplemented with mobile tracking detections collected during July-September 2012 in Lake Scanewa. Mobile tracking was done using a boat to slowly move through the reservoir while monitoring a telemetry receiver for detections of tagged fish. When a tagged fish was located, we recorded its position (latitude and longitude) using a globalpositioning system, the date and time of detection, and the water temperature reading emitted by the transmitter, which was displayed on the receiver. Mobile tracking occurred two times per week beginning in mid-July and ending in early-September.

\section{Data Analysis}

We used two approaches to characterize water temperature patterns in Lake Scanewa during 2012. First, we compared daily water temperatures measured at the Cowlitz Falls Fish Facility during 2012 to daily water temperature data collected during 2008-11 and 2013-16 to provide context for conditions observed during this study. To do this, we plotted daily water temperatures from June 1 to August 31 for each year during 2008-16. This allowed visual assessment of water temperature patterns in 2012 relative to conditions observed during the 9year period. Second, we summarized depth-specific water temperature data collected at 2-h intervals at three locations in Lake Scanewa. For each temperature logger we averaged 2-h data records within a single day to generate a daily-averaged value for that location and depth. The daily-averaged water temperatures were then plotted by location and depth to describe water temperature distributions within the water column at specific sites in the reservoir. 
Temperature-use patterns of adult spring Chinook salmon were examined using dailyaveraged water temperature records. Individual water temperature records obtained from temperature-sensing radio transmitters were averaged for each calendar day in the study period. This was accomplished by calculating the mean temperature value for tagged individuals on each date they were detected in the reservoir. This information was used to develop a time-series of the thermal history of each tagged fish in the reservoir. We also calculated daily-averaged thermal histories for all tagged fish in the reservoir by pooling all detections on each calendar day. These data are presented for the entire reservoir and for the three reservoir arms.

\section{Results}

\section{Fish Tagging and Release}

A total of 51 adult spring Chinook salmon of hatchery origin were tagged and released during the study period. Fish releases began on June 19, 2012, and continued weekly through August 14, 2012 (table 2). A greater number of female Chinook salmon were tagged and released than male Chinook salmon. Ten fish were released in June, 30 fish in July, and 11 in August (table 2).

Table 2. Number of male and female hatchery origin Chinook salmon (Oncorhynchus tshawytscha) tagged and released to evaluate water temperature-use patterns in Lake Scanewa, Cowlitz River, Washington, 2012.

\begin{tabular}{lcc}
\hline \multicolumn{1}{c}{ Release date } & Males & Females \\
\hline June 19 & 2 & 5 \\
June 26 & 1 & 2 \\
July 3 & 2 & 3 \\
July 10 & 2 & 5 \\
July 17 & 2 & 8 \\
July 24 & 1 & 4 \\
July 31 & 0 & 3 \\
August 7 & 1 & 4 \\
August 14 & 1 & 5 \\
Total & 12 & 39 \\
\hline
\end{tabular}

\section{Water Temperature Monitoring in Lake Scanewa}

Water temperature at the Cowlitz Falls Fish Facility was in the $5.5-11{ }^{\circ} \mathrm{C}$ range from April 16 to July 6, 2012, and increased to a high of $18.5^{\circ} \mathrm{C}$ on August 15, 2012 (fig. 2).

Generally, 2012 appeared to be an average to cool water temperature year in Lake Scanewa compared to other years during 2008-16 (fig. 2). Water temperature exceeded $19{ }^{\circ} \mathrm{C}$ at the Cowlitz Falls Fish Facility in 6 of the 9 years (2009-10 and 2013-16) and exceeded $20^{\circ} \mathrm{C}$ in 4 of the 9 years (2009 and 2014-16) during that period. Conditions were warmest in 2015 and coolest in 2008 (fig. 2).

Water temperature was similar throughout the water column at each of the three reservoir locations during July, but distinct temperature layers appeared at each location during August and September (fig. 3). In some cases, surface temperature exceeded $20^{\circ} \mathrm{C}$, but on most dates water temperature was less than $16^{\circ} \mathrm{C}$ at the deepest sensor at each location (fig. 3 ). 


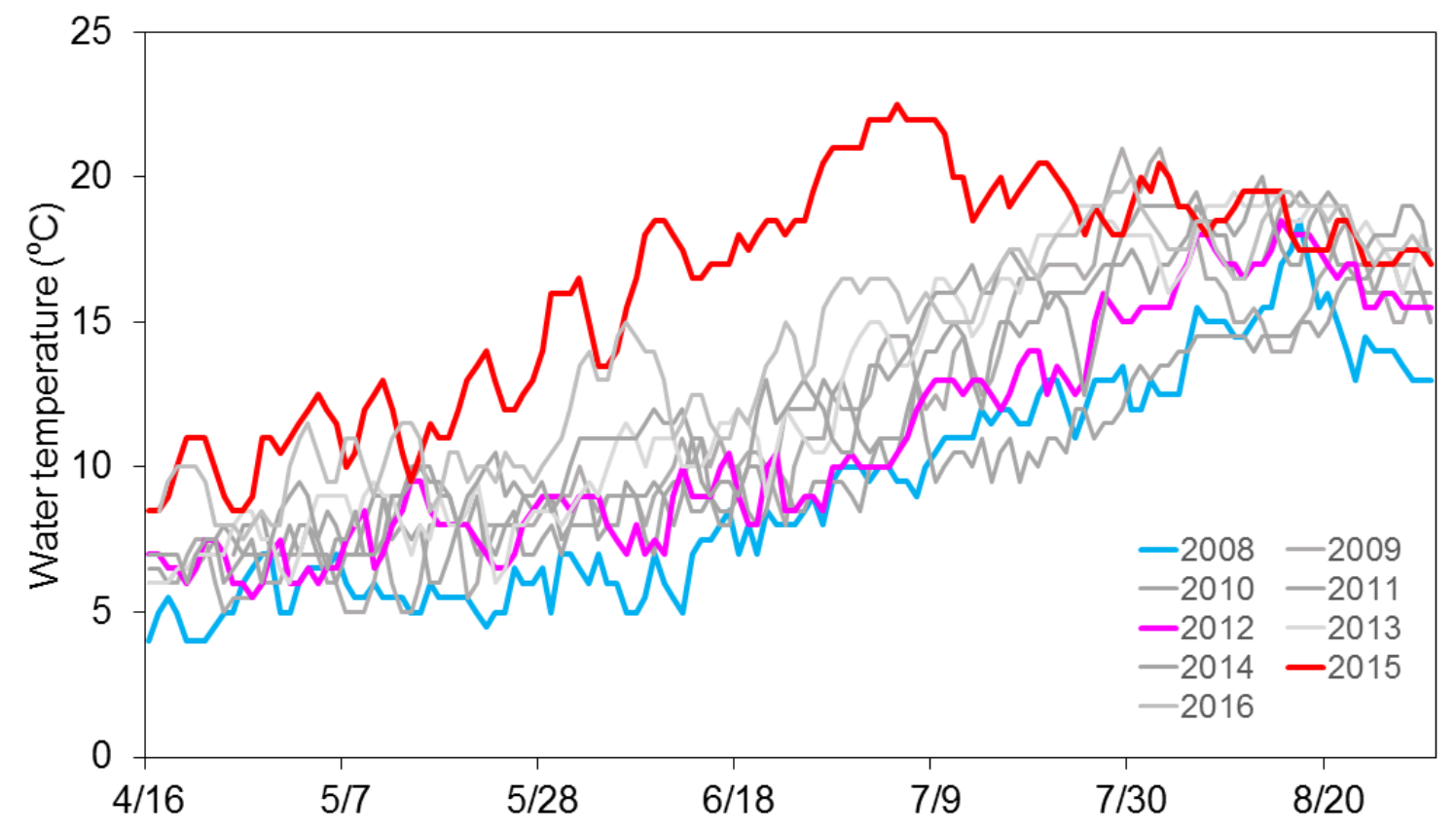

Figure 2. Graph showing daily water temperature at the Cowlitz Falls Fish Facility, Cowlitz Falls Dam, Washington, from April 16 to August 31, 2008-16. 


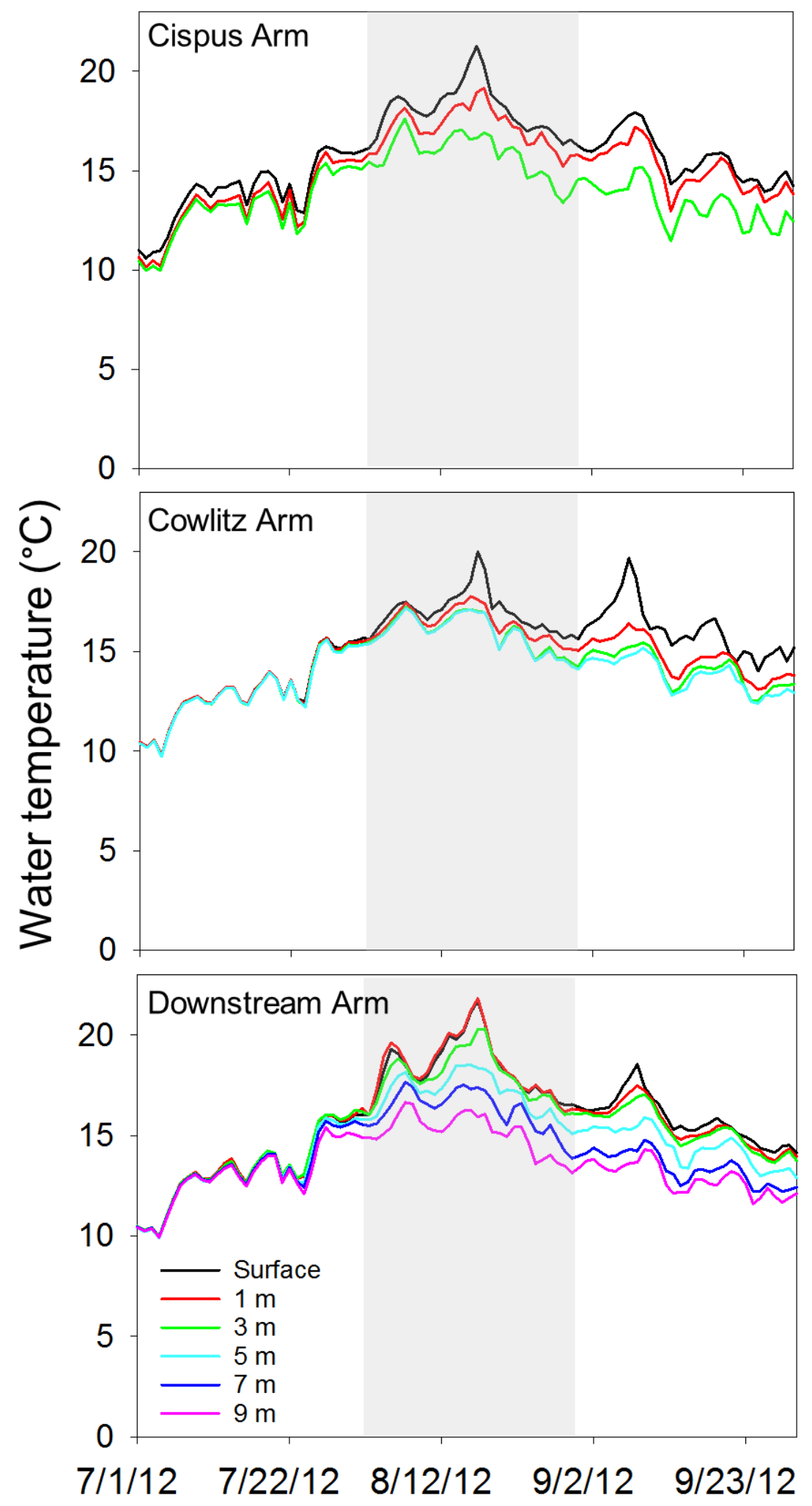

Figure 3. Graph showing depth-specific mean daily water temperatures at three sites in Lake Scanewa, Cowlitz River, Washington, July-September 2012. Shaded areas show August. ${ }^{\circ} \mathrm{C}$, degrees Celsius; $\mathrm{m}$, meter. 


\section{Water-Temperature Use by Adult Spring Chinook Salmon in Lake Scanewa}

During 2012, 930,056 water temperature records were collected from temperaturesensing radio transmitters implanted in adult spring Chinook salmon in Lake Scanewa. The average number of records collected from individual fish was 18,237 (range $=36-82,558$ ). Tagged fish were detected throughout the reservoir each month from June to October 2012, with the greatest number of fish detected in July and August (table 3). Many tagged spring Chinook salmon remained in the reservoir throughout the study ( 21 fish; 41 percent), while others moved upstream into the Cispus River (16 fish; 31 percent) and the Cowlitz River (12 fish; 24 percent), or moved downstream and passed Cowlitz Falls Dam (2 fish; 4 percent). Daily-averaged temperature histories of three randomly-selected study fish are shown in figure 4 as examples of temperature histories of tagged fish.

Water-temperature-use patterns changed monthly but most detections occurred within the 9-18 ${ }^{\circ} \mathrm{C}$ range (table 4). In June, 94 percent of the temperature records collected were in the 9$11{ }^{\circ} \mathrm{C}$ range. In July, 99 percent of the temperature records were in the $10-16{ }^{\circ} \mathrm{C}$ range. Tagged fish occupied the warmest temperature range in August with 99 percent of the temperature records in the $12-18{ }^{\circ} \mathrm{C}$ range. In September, 96 percent of the temperature records were in the $10-15{ }^{\circ} \mathrm{C}$ range. Finally, 96 percent of the temperature records from October were in the $11-14$ ${ }^{\circ} \mathrm{C}$ range (table 4). Daily-averaged water-temperature-use data show that tagged fish primarily were found in water less than $16^{\circ} \mathrm{C}$ in Lake Scanewa during June-October 2012 (fig. 5). Dailyaveraged water temperature of tagged spring Chinook salmon exceeded $16^{\circ} \mathrm{C}$ on 10 dates during the entire study period (fig. 5). Tagged Chinook salmon occupied similar water temperatures in the three arms of Lake Scanewa during June and most of July but were found in cooler water in the Cispus Arm of the reservoir during August-October 2012 (fig. 6). On average, daily water temperature-use by tagged Chinook salmon in the Cispus Arm was $2.3{ }^{\circ} \mathrm{C}$ cooler than daily water-temperature use by tagged fish in the Cowlitz and downstream arms of the reservoir.

Table 3. Number of radio-tagged Chinook salmon (Oncorhynchus tshawytscha) detected monthly from June to October 2012, Lake Scanewa, Cowlitz River, Washington. Data are shown for the entire reservoir and for the three arms of the reservoir.

\begin{tabular}{lcccc}
\hline \multirow{2}{*}{ Month } & \multicolumn{4}{c}{ Location } \\
\cline { 2 - 5 } & Entire reservoir & Cispus arm & Cowlitz arm & Downstream arm \\
\hline June & 10 & 3 & 10 & 6 \\
July & 40 & 31 & 38 & 33 \\
August & 40 & 33 & 32 & 32 \\
September & 17 & 16 & 6 & 11 \\
October & 4 & 3 & 1 & 1 \\
\hline
\end{tabular}



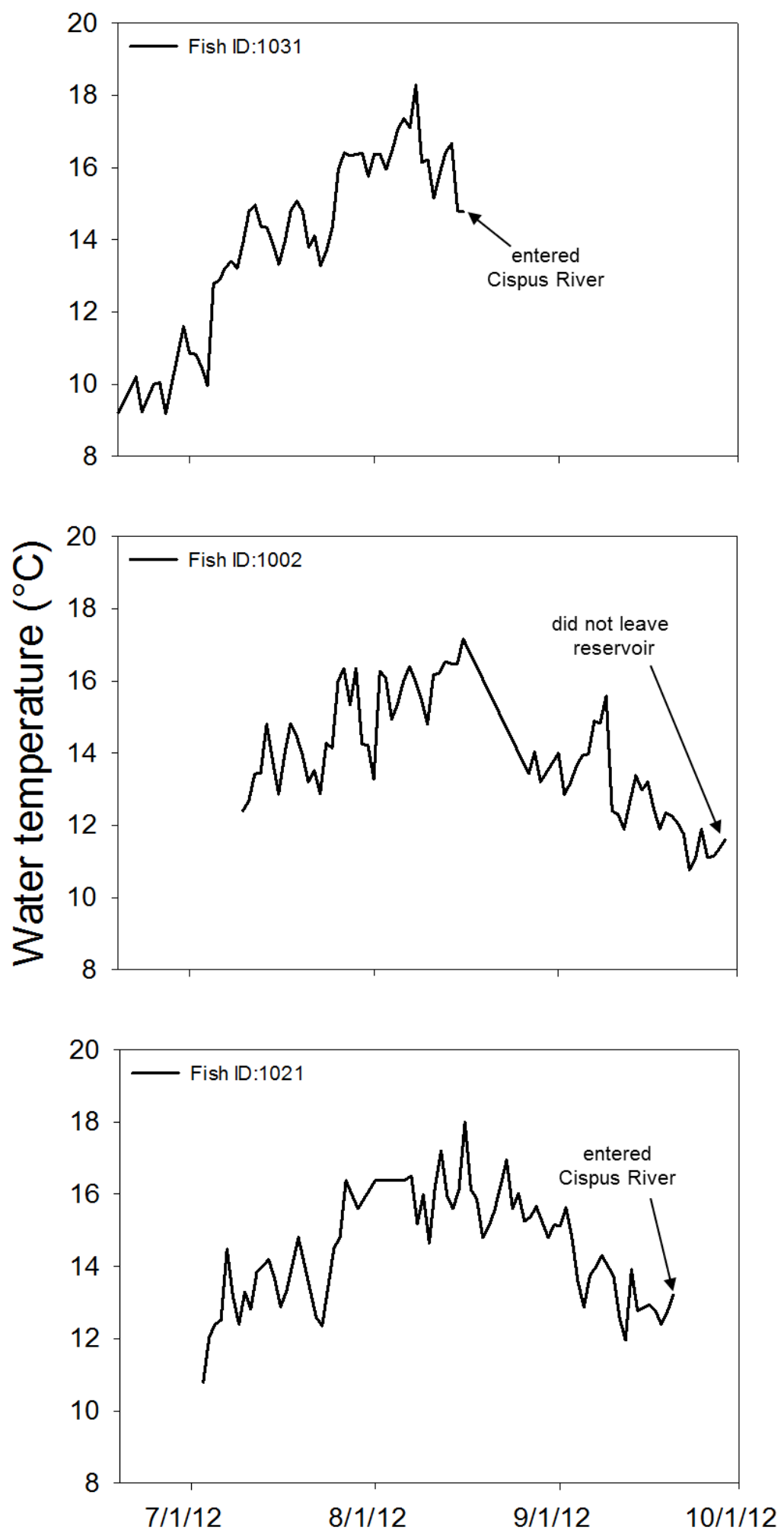

Figure 4. Graph showing mean daily water-temperature use by three individual adult Chinook salmon (Oncorhynchus tshawytscha) in Lake Scanewa, Cowlitz River, Washington, 2012. ${ }^{\circ} \mathrm{C}$, degrees Celsius. 
Table 4. Number of temperature records collected by 1 degree Celsius intervals from radio transmitter detections in Lake Scanewa, Cowlitz River, Washington, during June-October 2012.

[Percent of temperature records by month are in parentheses. ${ }^{\circ} \mathrm{C}$, degrees Celsius]

\begin{tabular}{cccccc}
\hline $\begin{array}{c}\text { Water } \\
\text { temperature }\left({ }^{\circ} \mathrm{C}\right)\end{array}$ & June & July & Month & October \\
\cline { 2 - 5 } & $15(0.03)$ & $4(0.00)$ & - & $41(0.03)$ & - \\
8 & $2,562(4.52)$ & $22(0.01)$ & - & $61(0.04)$ & - \\
9 & $15,259(26.89)$ & $860(0.27)$ & $11(0.00)$ & $69(0.04)$ & - \\
10 & $24,302(42.83)$ & $28,725(9.14)$ & $218(0.05)$ & $24,035(15.52)$ & $25(3.42)$ \\
11 & $13,759(24.25)$ & $14,396(4.58)$ & $2,296(0.57)$ & $35,922(23.19)$ & $84(11.47)$ \\
12 & $837(1.47)$ & $22,853(7.27)$ & $21,322(5.29)$ & $29,214(18.86)$ & $215(29.37)$ \\
13 & $8(0.01)$ & $76,167(24.24)$ & $31,349(7.77)$ & $20,681(13.35)$ & $33(4.51)$ \\
14 & - & $111,091(35.35)$ & $84,448(20.93)$ & $30,526(19.71)$ & $371(50.68)$ \\
15 & - & $26,237(8.35)$ & $67,561(16.75)$ & $8,942(5.77)$ & $4(0.55)$ \\
16 & - & $30,898(9.83)$ & $86,885(21.54)$ & $4,558(2.94)$ & - \\
17 & - & $2,871(0.91)$ & $58,733(14.56)$ & $768(0.50)$ & - \\
18 & - & $141(0.05)$ & $48,977(12.14)$ & $76(0.05)$ & - \\
19 & - & $14(0.00)$ & $1,523(0.38)$ & $1(0.00)$ & - \\
20 & - & - & $84(0.02)$ & $2(0.00)$ & - \\
Total & 56,742 & 314,279 & 403,407 & 154,896 & 732 \\
\hline
\end{tabular}

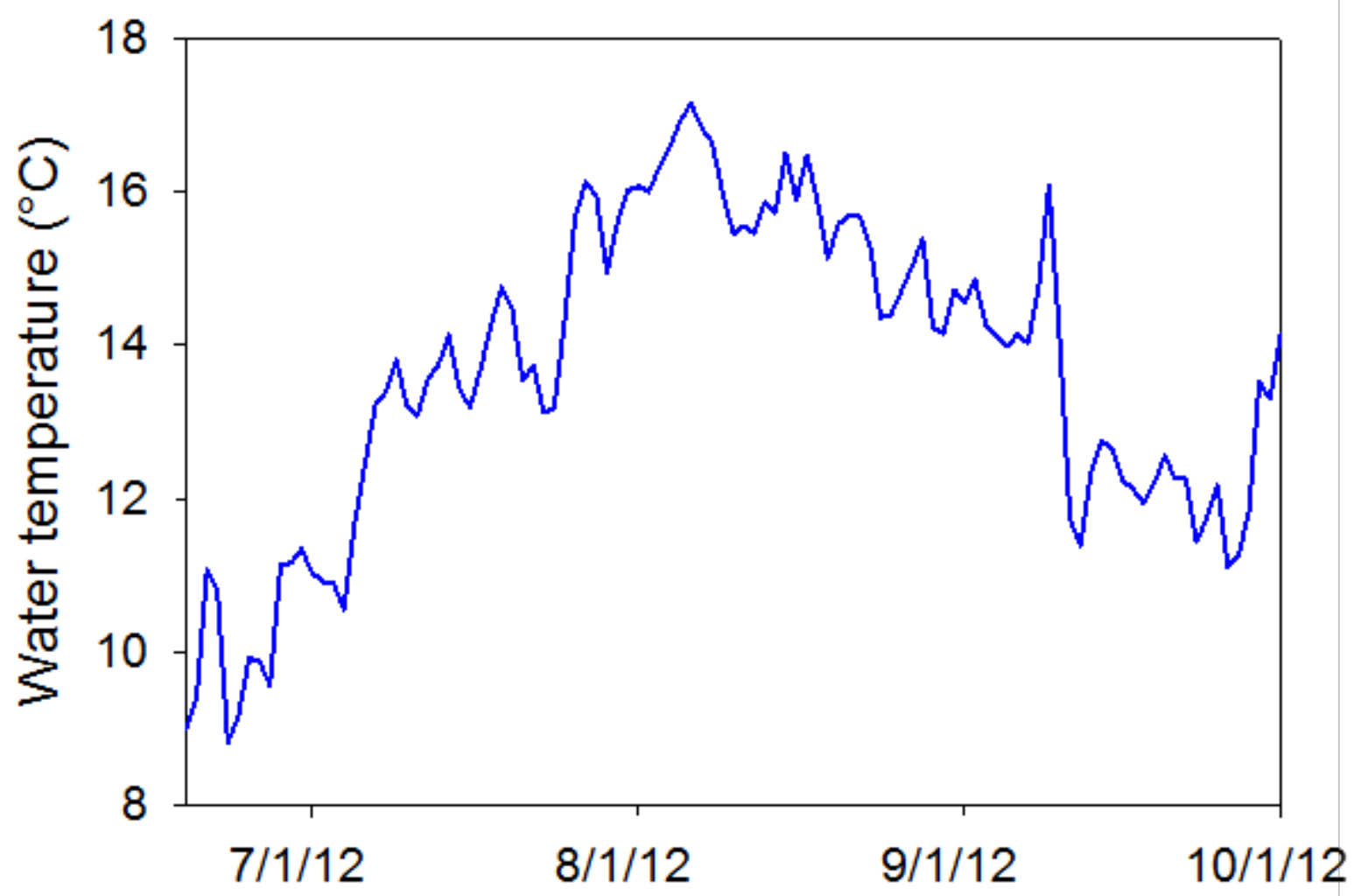

Figure 5. Graph showing mean daily water-temperature use by tagged adult Chinook salmon in Lake Scanewa, Washington, 2012. 


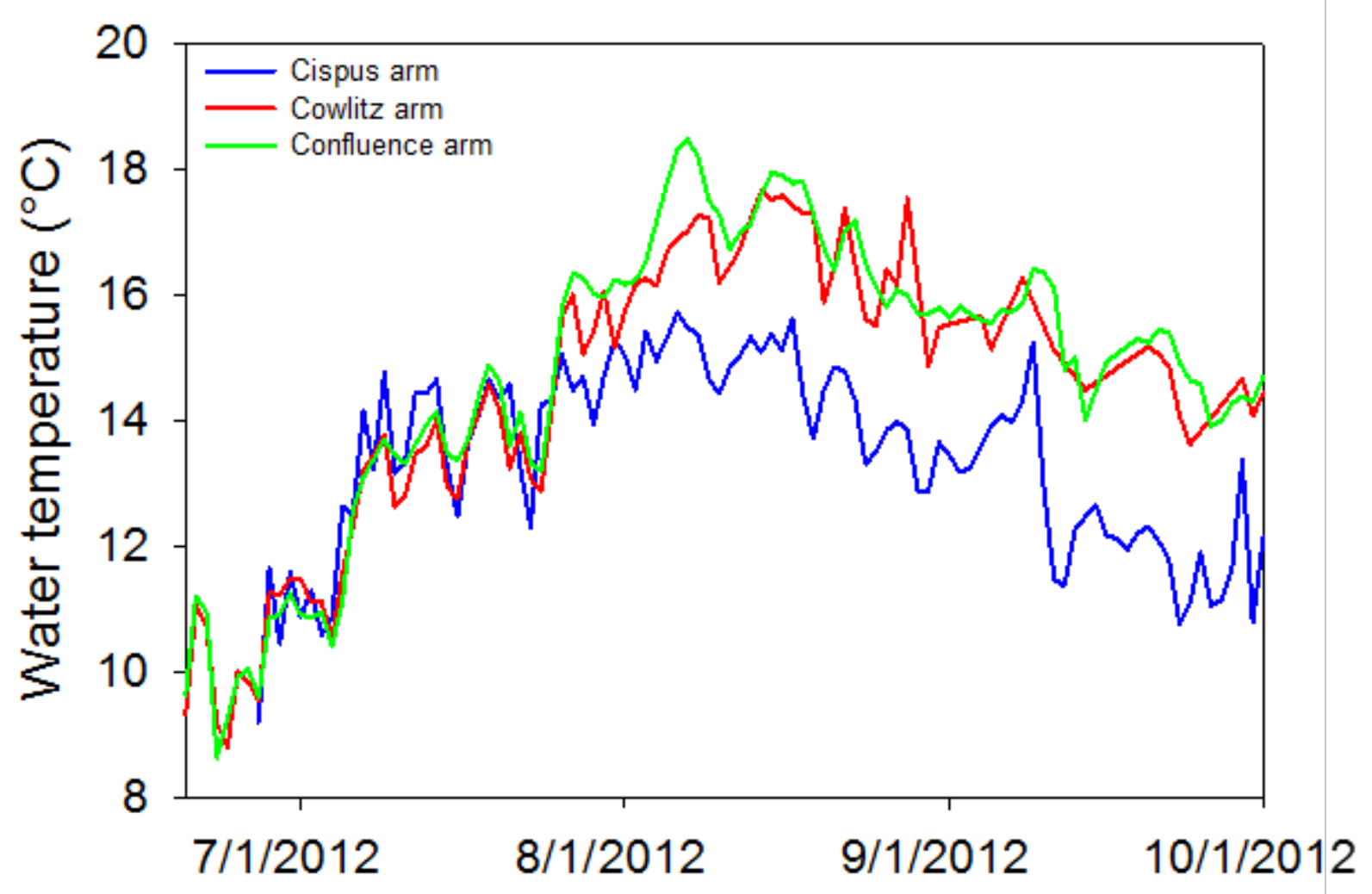

Figure 6. Graph showing mean daily water-temperature use by adult Chinook salmon in three regions (Cispus arm, Cowlitz arm, and Downstream arm) of Lake Scanewa, Washington, 2012. Water temperature data were collected using temperature-sensing radio transmitters implanted in study fish.

\section{Discussion}

This report described water temperature use by adult hatchery-origin spring Chinook salmon in Lake Scanewa during June-October 2012. The use of thermographs and temperaturesensing radio transmitters allowed us to describe water temperature availability in the reservoir and to continuously monitor water temperatures occupied by multiple tagged fish. We found that tagged fish occupied water temperatures less than $16^{\circ} \mathrm{C}$ during most of the study period. Water temperature peaked in the reservoir during August, when we observed that 49 percent of the detections of tagged fish were in water temperatures of $16-20^{\circ} \mathrm{C}$. Other studies have indicated that exposure to water temperature equal to or greater than $18^{\circ} \mathrm{C}$ is stressful for spring Chinook salmon (Berman, 1990; McCullough and others, 2001; Keefer and others, 2015). In this study, tagged fish detections in water temperatures $18-20^{\circ} \mathrm{C}$ comprised 13 percent of the total detections in August. Data collected during this study indicate that adult hatchery-origin spring Chinook salmon were able to locate and use water temperatures in Lake Scanewa less than levels reported as stressful for the species in other locations (Berman, 1990; McCullough and others, 2001 Keefer and others, 2015;). However, thermal conditions in the reservoir were relatively mild in 2012 and appear to have been closer to the coolest water temperature year (2008) than other years in the 2008-16 timeframe. Thus, it may be useful to do a similar study in the future 
to determine if thermal exposure to stressful conditions occur at a higher rate during a year when the reservoir has warmer water conditions.

Tagged spring Chinook salmon in the Cispus Arm of the reservoir occupied water temperatures substantially cooler than elsewhere in the reservoir during August and September. That finding suggests that the Cispus River provides an important source of cool water refugia in Lake Scanewa, and that adult spring Chinook salmon can locate and use this resource. Berman and Quinn (1991) monitored temperature use by adult spring Chinook salmon in the Yakima River and found that tagged fish maintained (on average) an internal body temperature $2.5{ }^{\circ} \mathrm{C}$ less than ambient river temperatures by holding in areas where thermal refuges were present. The importance of this cool water resource in Lake Scanewa could become increasingly important in warm water years and with climate change, further supporting the need for additional research on this topic to better understand how these factors change annually.

\section{Acknowledgments}

We thank Bonneville Power Administration for funding that supported the Washington Department of Fish and Wildlife research effort. John Serl, Eric Nissel, and Wade Heimbigner with the Washington Department of Fish and Wildlife and the Pacific States Marine Fisheries Commission helped with fish tagging and mobile tracking during the study. Ryan Tomka and Will Hurst (USGS) assisted with data collection efforts. Additionally, we thank Tacoma Power for transporting and releasing all tagged fish during the study.

\section{References}

Berman, C.H., 1990, The effect of elevated holding temperatures on adult spring Chinook salmon reproductive success: Master's Thesis, University of Washington, Seattle, Washington.

Berman, C.H., and Quinn, T.P., 1991, Behavioral thermoregulation and homing by spring Chinook salmon, Oncorhynchus tshawytscha (Walbaum), in the Yakima River: Journal of Fish Biology, v. 39, p. 301-312.

Keefer, M.L., Peery, C.A., Ringe, R.R., and Bjornn, T.C., 2004, Regurgitation rates of intragastric radio transmitters by adult Chinook salmon and steelhead during upstream migration in the Columbia and Snake rivers: North American Journal of Fisheries Management, v. 24, no. 1, p. 47-54.

Keefer, M.L, Clabough, T.S, Jepsen, M.A., Naughton, G.P., Blubaugh, T.J., Joosten, D.C., and Caudill, C.C., 2015, Thermal exposure of adult Chinook salmon in the Willamette River basin: Journal of Thermal Biology, v. 48, p. 11-20.

Kock, T.J., Ekstrom, B.K., Liedtke, T.L., Serl, J.D., and Kohn, M., 2016, Behavior patterns of adult steelhead, Chinook salmon, and coho salmon released into the upper Cowlitz River Basin, Washington, 2005-2009 and 2012: U.S. Geological Survey Open-File Report 20161144, 36 p., accessed January 18, 2019, at http://dx.doi.org/10.3133/ofr20161144.

Kock, T.J., Perry, R.W., Pope, A.C., Serl, J.D., Kohn, M., and Liedtke, T.L., 2018, Responses of hatchery- and natural-origin adult spring Chinook salmon to a trap-and-haul reintroduction program: North American Journal of Fisheries Management, v. 38, no. 5, p. 1004-1016.

McCullough, D.A., Spalding, Shelley, Sturdevant, Debra, Hicks, Mark, 2001, Summary of technical literature examining the physiological effects of temperature on salmonids: U.S. Environmental Protection Agency, EPA-910-01-005, 291 p. 
Serl, J.D., and Morrill, C.F., 2011, Summary report for the 1996 to 2009 seasonal operation of the Cowlitz Falls Fish Facility and related upper Cowlitz River watershed anadromous fish reintroduction efforts: Report by the Washington Department of Fish and Wildlife to the U.S. Department of Energy, Bonneville Power Administration, 174 p., accessed January, 2019, at https://www.cbfish.org/Document.mvc/DocumentViewer/P160564/200304800-2.pdf. 
Publishing support provided by the U.S. Geological Survey Science Publishing Network, Tacoma Publishing Service Center

For more information concerning the research in this report, contact the Director, Western Fisheries Research Center

U.S. Geological Survey 6505 NE 65th Street

Seattle, Washington 98115-5016

https://www.usgs.gov/centers/wfrc 


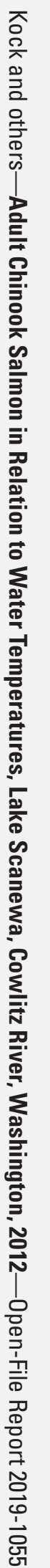

